\title{
Effect of Mg Addition (in Zinc Bath) on Galvanized Sheet Quality
}

\author{
S K Shukla ${ }^{1, *}$, M. Deepa ${ }^{2}$, Santosh Kumar ${ }^{1}$ \\ ${ }^{1}$ Steel Product Group, Research and Development Centre for Iron and Steel, Steel Authority of India Limited, Ranchi, 834002, India \\ ${ }^{2}$ Physical Metallurgy Group, Research and Development Centre for Iron and Steel, Steel Authority of India Limited, Ranchi, 834002, India
}

\begin{abstract}
In order to improve the corrosion resistance of the conventional hot dip galvanized sheets, a new type of $\mathrm{Zn}-\mathrm{Mg}$ coating has been developed. Experiments were conducted in HDPS by varying zinc bath Mg level, bath temperature \& dipping time. It has been found that steel sheet galvanized in zinc bath composition of $0.50 \% \mathrm{Mg}, 0.25 \% \mathrm{Al}, 0.08 \% \mathrm{Si} \&$ $0.08 \% \mathrm{Sb}$ and processed at bath temperature of $\sim 460^{\circ} \mathrm{C}$ and dipping time : $2.0 \mathrm{sec}$. results in best combination of properties in terms of corrosion rate : 4.0 mpy $\left(\sim 1 / 3^{\text {rd }}\right.$ w.r.t conventional GI sheets : $\left.\sim 12 \mathrm{mpy}\right)$, formability of the composite (Ev $: 10.4$ $\mathrm{mm}$ for sheet thickness of $0.8 \mathrm{~mm}$ ) at par with substrate material, coating adherence as per Lock Forming Quality (LFQ) standard and appearance bright and smooth. The imp roved corrosion resistance of newly developed coating is attributed to the presence of $\mathrm{Mg}-\mathrm{Zn}$ intermetallic phases along the grain boundary inhibiting the cathodic reaction as well as formation of protective $\mathrm{MgO} \&$ protective corrosion products of zinc. The presence of $\mathrm{Sb}$ in the galvanizing bath has also led to improved intergranular corrosion resistance. Superior formability, adherence and appearance of the coating is due to presence of adequate $\mathrm{Al} \& \mathrm{Si}$ level in the galvanizing bath, which led to suppression of brittle Fe- $\mathrm{Zn}$ phase formation at the coating-steel interface.
\end{abstract}

Keywords Zn-Mg Coating, Corrosion Resistance, Formability, Coating Simulation

\section{Introduction}

Zinc coated sheets are widely used in Construction, Automotive and appliance industry. The demand by the customers for the performance of the coated sheets with respect to corrosion protection, formability, jo inability and paintability is steadily increasing. The demand for extended longevity of the galvanized sheet is increasing to meet the demand for maintenance free products. To meet this demand the corrosion resistance of the galvanized sheets need to be improved. Corrosion resistance of the zinc coated products can be improved by alloying the galvanizing bath with aluminium, nickel, magnesium and other alloying elements. Addition of aluminium to zinc bath is one of the most useful development so far. Nevertheless, there is scope for further development in terms of coating parameter, composition and lower bath temperature to improve corrosion resistance and other properties, and at a lower cost so that it can be economically exploited.

As regards to alloying elements, in addition to $\mathrm{Al}$, several reports have published the effect of $\mathrm{Mg}[1,2]$. $\mathrm{Mg}$ has the best corrosion resistance, lowest density among metals, superior

* Corresponding author:

skshukla@sail-rdcis.com (S K Shukla)

Published online at http://journal.sapub.org/ijme

Copyright (C) 2012 Scientific \& Academic Publishing. All Rights Reserved specific strength and high electro-negativity in emf series. Also, Zn-Mg alloys can offer low bath temperature[3,4]. Further, It has also been reported that small amount of $\mathrm{Si}$ addition in zinc bath improves the coating ductility [5]. In view of the above, the aim of the present work was to find out the optimum level of $\mathrm{Mg}$ in zinc bath as well as optimised galvanizing parameters such as bath temperature, dipping time etc. for achieving improved properties in terms of corrosion resistance, formability properties along with adequate peel-off resistance of the zinc coating. In addition to above, for improving the intergranular corrosion resistance of the $\mathrm{Zn}-\mathrm{Mg}-\mathrm{Al}-\mathrm{Si}$ coating, possibility of replacing $\mathrm{Pb}$ with $\mathrm{Sb}$ in zinc bath has also been explored. This will also help in addressing the environmental issues related with $\mathrm{Pb}$.

\section{Experimental}

During coating simulation experiments, Commercial Quality Cold Rolled (CQCR) sheets (thickness : $0.8 \mathrm{~mm}$ ) were galvanized in HDPS by varying zinc bath $\mathrm{Mg}$ level (0.25-0.75\%), bath temperature $\left(420-460^{\circ} \mathrm{C}\right) \&$ dipping time (2.0-4.0 sec.), while A1, Si \& Sb levels were maintained at $\sim 0.25 \%, \quad \sim 0.08 \% \quad \& \quad \sim 0.08 \%$ respectively. Chemical composition of the steel substrate used in simulation studies has been shown in Table I. Process variables and their ranges have been shown in Table II. 
Table 1. Chemical composition of cold rolled substrate used in Simulation Studies

\begin{tabular}{|c|c|}
\hline Element & Wt (\%) \\
\hline $\mathrm{C}$ & 0.06 \\
\hline $\mathrm{Mn}$ & 0.30 \\
\hline $\mathrm{Si}$ & 0.030 \\
\hline $\mathrm{S}$ & 0.012 \\
\hline $\mathrm{P}$ & 0.015 \\
\hline $\mathrm{Al}$ & 0.030 \\
\hline $\mathrm{N}$ & $50 \mathrm{ppm}$ \\
\hline
\end{tabular}

Table 2. Process variables and their ranges during simulation experiments

\begin{tabular}{|c|c|c|}
\hline S.No. & $\begin{array}{c}\text { Process } \\
\text { variable }\end{array}$ & Range \\
\hline 1. & $\begin{array}{c}\text { Mg level in } \\
\text { zinc bath }\end{array}$ & $0.25-0.75 \%$ \\
\hline 2. & Bath Temp. & $420-460^{\circ} \mathrm{C}$ \\
\hline 3. & $\begin{array}{c}\text { Dipping } \\
\text { Time }\end{array}$ & $2.0-4.0 \mathrm{sec}$. \\
\hline
\end{tabular}

In simulation tests, CQCR sheets of size $200 \mathrm{~mm}$ (L) $\mathrm{x}$ $120 \mathrm{~mm}(\mathrm{~W})$ were heated at the rate of $30^{\circ} \mathrm{C} / \mathrm{s}$ to annealing temperature of $750^{\circ} \mathrm{C}$ and soaked at this temperature for 45 sec. in annealing atmosphere of $20 \% \mathrm{H}_{2}+80 \% \mathrm{~N}_{2}$. Dew point of annealing atmosphere was kept at $\sim-20^{\circ} \mathrm{C}$ during experimentation. Subsequent to annealing, samples were cooled with $\mathrm{N}_{2}$ gas upto near bath temperature $\left(5^{\circ} \mathrm{C}\right.$ more than the bath temperature) at the rate of $\sim 4^{\circ} \mathrm{C} / \mathrm{s}$ and subsequent to dipping in the zinc bath, samples were cooled at the rate of $10^{\circ} \mathrm{C} / \mathrm{s}$ till room temperature.

Experimental galvanized sheet samples were characterized in terms of coating thickness, corrosion rate, formability, coating adherence $\&$ microstructures. Coating Thickness (CT) of the galvanized samples was measured using Defalsko Coating Thickness Gauge (Model : Positector 6000). Formability characteristics of GI sheets were evaluated through Erichsen Cup Tester. During erichsen cup test, the point at which the cracks/peel-off of the coating begins, punch movement at that point was taken as the erichsen cup value of the composite. Coating adherence of the coated sheets was assesses through Lock Forming Tester. Corrosion characteristics of GI sheets were assessed through Taffel plot using potentiostat under the following conditions : Test Solution : $3.5 \% \mathrm{NaCl}$

Reference Electrode : Silver-Silver chloride.

Scan Rate : $0.1 \mathrm{mv} / \mathrm{s}$.

Scan Range : $\pm 20 \mathrm{mv}$.

Metallographic analysis of simulated GI sheet samples was carried out using Scanning Electron Microscope attached with EDAX system.

\section{Results \& Discussion}

Simu lated galvanized sheets were characterized in terms of coating thickness, Corrosion rate, formability properties and coating adherence. The results have been shown in Table III.

\subsection{Corrosion Resistance of $\mathrm{Zn}-\mathrm{Mg}$ Coated Sheets}

Corrosion resistance of the Zn-Mg-A l-Si coated sheets, measured through electropolarisation test using Taffel plot, varied in the range of 4.0 to $10.5 \mathrm{mpy}$ (compared to $12-15$ mpy observed in conventional zinc coated sheets), depending on the processing condition. For the coated sheets, galvanized in $0.25 \% \mathrm{Mg}$ bath, corrosion rate varied from 8.0 to 10.5 mpy., while the corrosion rates of the galvanized sheets of $0.50 \& 0.75 \% \mathrm{Mg}$ bath was found in the range of 4.0 to 7.6 mpy. In Fig. 1, variation of corrosion rate with $\mathrm{Mg}$ content is shown.

Table 3. Properties of $\mathrm{Zn}-\mathrm{Mg}$ coated sheets

\begin{tabular}{|c|c|c|c|c|c|c|c|c|c|c|c|c|c|}
\hline \multirow[t]{2}{*}{ S.No. } & \multirow[t]{2}{*}{$\begin{array}{c}\text { Bath } \\
\text { Composition }\end{array}$} & \multicolumn{3}{|c|}{$\begin{array}{l}\text { Coat ing Thickness } \\
(\mu \mathrm{m})\end{array}$} & \multicolumn{3}{|c|}{ Corrosion Rate (mpy) } & \multicolumn{3}{|c|}{$\begin{array}{l}\text { Erichsen cup value } \\
(\mathrm{mm})\end{array}$} & \multicolumn{3}{|c|}{$\begin{array}{l}\text { Coating adherence } \\
\text { (LFQT est) }\end{array}$} \\
\hline & & Min. & $\begin{array}{c}\text { Max } \\
.\end{array}$ & Avg. & Min. & Max. & Avg. & Min. & Max & Avg. & Min. & Max. & Avg. \\
\hline 1. & $\begin{array}{c}\mathrm{Zn}-0.25 \mathrm{Mg}-0 . \\
25 \mathrm{Al}-0.08 \mathrm{Si}-0 . \\
08 \mathrm{Sb}\end{array}$ & 18.6 & 23.6 & 20.8 & 8.6 & 10.5 & 9.2 & 8.8 & 10.0 & 9.2 & $\begin{array}{l}\text { Minor cracks } \\
\text { in one } \\
\text { sample }\end{array}$ & $\begin{array}{c}\text { Excellen } \\
t\end{array}$ & $\mathrm{O} . \mathrm{K}$ \\
\hline 2. & $\begin{array}{c}\mathrm{Zn}-0.50 \mathrm{Mg}-0 . \\
25 \mathrm{Al}-0.08 \mathrm{Si}-0 . \\
08 \mathrm{Sb}\end{array}$ & 20.4 & 24.8 & 22.3 & 4.0 & 6.4 & 5.6 & 9.2 & 10.4 & 9.8 & $\mathrm{O} . \mathrm{K}$ & $\begin{array}{c}\text { Excellen } \\
t\end{array}$ & $\begin{array}{c}\text { Excellen } \\
t\end{array}$ \\
\hline 3. & $\begin{array}{c}\mathrm{Zn}-0.75 \mathrm{Mg}-0 . \\
25 \mathrm{Al}-0.08 \mathrm{Si}-0 . \\
08 \mathrm{Sb}\end{array}$ & 21.4 & 25.8 & 23.8 & 4.5 & 7.4 & 6.0 & 8.8 & 10.4 & 9.6 & $\begin{array}{l}\text { Minor cracks } \\
\text { in one } \\
\text { sample }\end{array}$ & $\begin{array}{c}\text { Excellen } \\
t\end{array}$ & $\mathrm{O} . \mathrm{K}$ \\
\hline
\end{tabular}




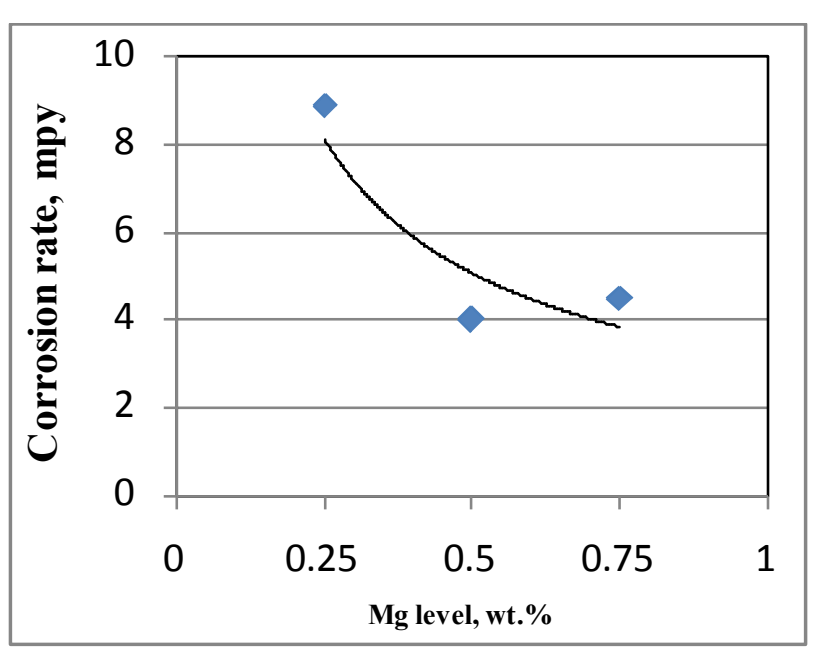

Figure 1. Effect of $\mathrm{Mg}$ on corrosion rates of $\mathrm{Zn}-\mathrm{Mg}$ coated sheets

It can be seen that with increase in $\mathrm{Mg}$ content from 0.25 to $0.75 \%$ for a bath temperature of $460^{\circ} \mathrm{C}$ and dipping time of $2.0 \mathrm{sec}$, corrosion rate of the $\mathrm{Zn}-\mathrm{Mg}$ coated sheets decreases from 10.5 to 4.0 mpy. From the above it can be observed that increase in $\mathrm{Mg}$ content from 0.25 to $0.50 \%$ improves the corrosion rate by more than $50 \%$, however, further increase of $\mathrm{Mg}$ level from $0.50 \%$ to $0.75 \%$ doesn't results in any further improvement in corrosion rate of the coated sheets. Corrosion rates of the coated sheets galvanized in $0.75 \% \mathrm{Mg}$ bath was found more or less same as that of the $0.50 \% \mathrm{Mg}$ bath. High corrosion resistance of the material coated in ternary $\mathrm{Zn}-\mathrm{Mg}-\mathrm{Al}$ bath has been attributed to the segregation of $\mathrm{Al}$ and $\mathrm{Mg}$ at grain boundaries which forms $\mathrm{Zn} / \mathrm{Mg} / \mathrm{Al}$ ternary eutectic phase mixture[6]. It has been reported that zinc forms protective corrosion product with $\mathrm{Al}$ and $\mathrm{Mg}[6]$ and $\mathrm{Al}$ rich phase first corrodes, while surrounding ternary eutectic phase mixture remains stable[7,8]. Formation of this protective layer seems to be responsible for better corrosion resistance of $\mathrm{Zn}-\mathrm{Mg}$-Al coated sheet. In SEM micrographs (shown in Fig.2) of $0.25 \% \mathrm{Mg}$ coated sheets, formation of uniform and strong $\mathrm{Zn} / \mathrm{Mg} / \mathrm{Al}$ ternary mixture along the grain boundary was not observed. Though in some isolated regions, ternary mixture of $\mathrm{Zn} / \mathrm{Mg} / \mathrm{Al}$ was observed. This must have led to inferior corrosion resistance properties in $0.25 \% \mathrm{Mg}$ coated sheets as compared to $0.50 \& 0.75 \% \mathrm{Mg}$ coated sheets. However, in the SEM micrographs (shown in Fig. $3 \& 4$ ) of the coated sheets, galvanized in $0.50 \& 0.75 \%$ $\mathrm{Mg}$ bath, it can be clearly seen that there is very prominent and uniform formation of $\mathrm{Zn} / \mathrm{Mg} / \mathrm{Al}$ ternary eutectic phase mixtu re (composition; $\mathrm{Mg}: 0.77 \%, \mathrm{Al}: 1.73, \mathrm{Zn}: 92.79 \%$ ) at the grain boundaries due to segregation of $\mathrm{Al}$ and $\mathrm{Mg}$ at these sites leading to slower anodic dissolution of the $\mathrm{Mg}-\mathrm{Zn}$ intermetallic phases and formation of protective $\mathrm{MgO}$, which results in enhanced corrosion resistance of $\mathrm{Zn}-\mathrm{Mg}$-Al coated sheets $[9,10]$. Further, corrosion resistance of the $\mathrm{Zn}-\mathrm{Mg}$ coated sheets was also measured through salt spray test. The results are shown in Table IV. It can be seen that the corrosion resistance of the coated sheets galvanized in $\mathrm{Zn}-\mathrm{Mg}$-Al-Sb bath is much superior compared to those galvanized in $\mathrm{Zn}-\mathrm{Al}-\mathrm{Pb}, \mathrm{Zn}-\mathrm{Al}$ and pure zinc bath.
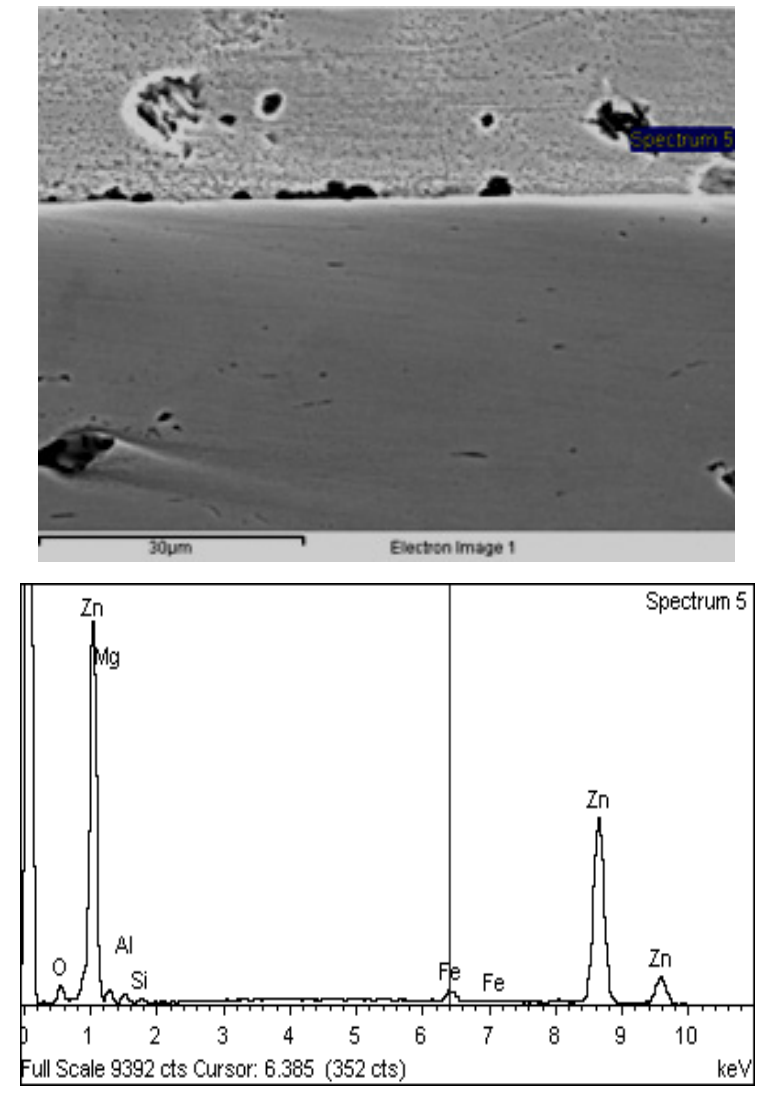

Figure 2. Microstructure and EDAX analysis of coated sheet galvanized in $0.25 \% \mathrm{Mg}$ bath
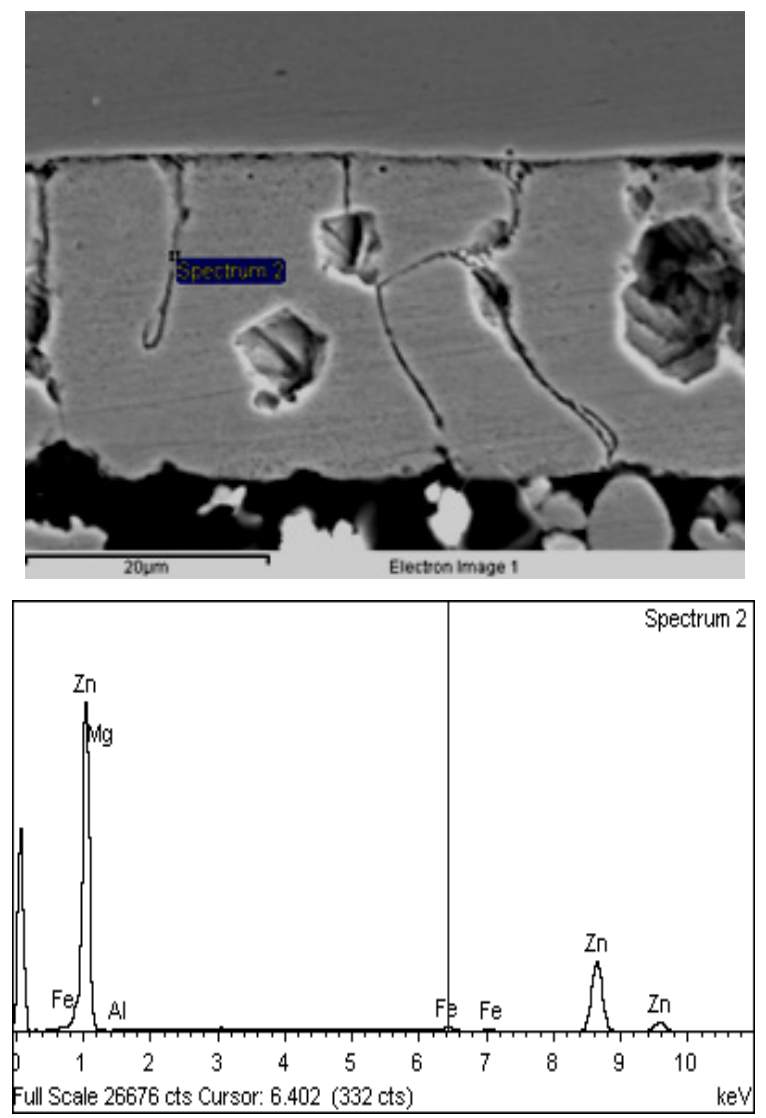

Figure 3. Microstructure and EDAX analysis of coated sheet galvanized in $0.50 \% \mathrm{Mg}$ bath 

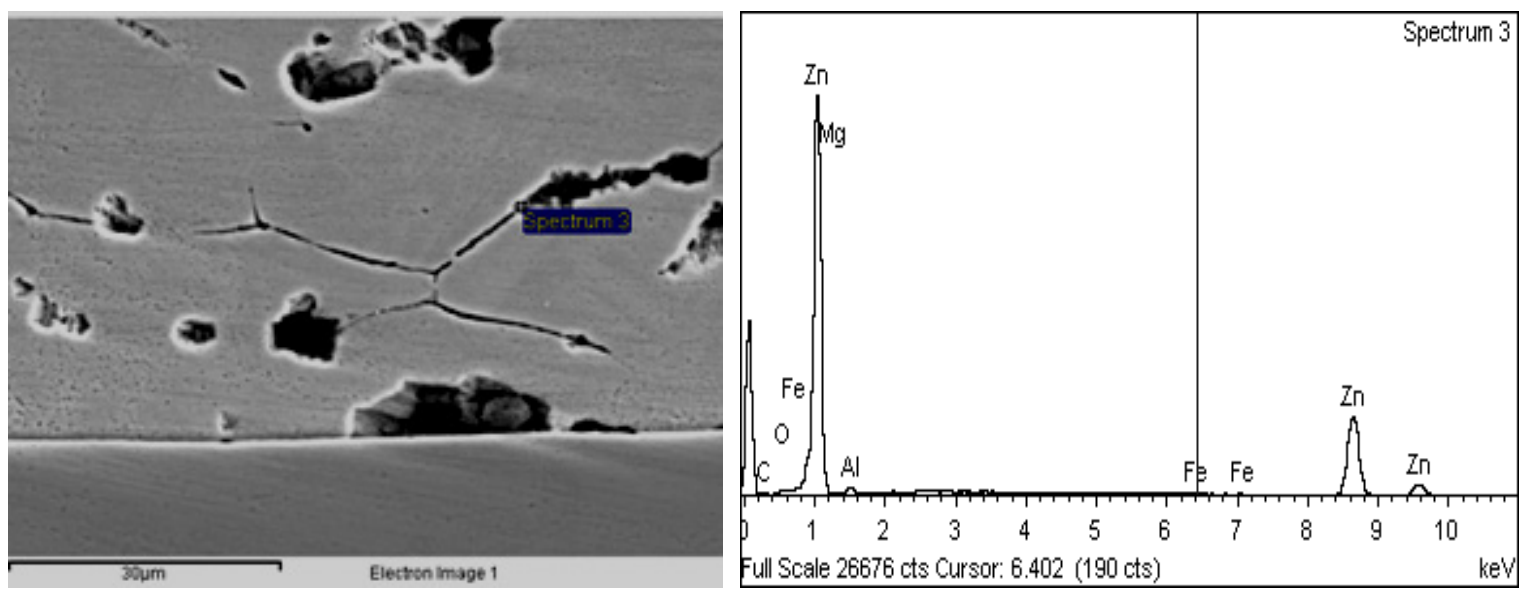

Figure 4. Microstructure and EDAX analysis of coated sheet galvanized in $0.75 \% \mathrm{Mg}$ bath

Table 4. Salt spray test results of the coated sheets

\begin{tabular}{|c|c|c|c|c|c|c|c|c|c|c|}
\hline \multirow[t]{2}{*}{ S.No. } & $\begin{array}{c}\text { Bath } \\
\text { composition }\end{array}$ & \multicolumn{9}{|c|}{ White rust $\%$} \\
\hline & & $\begin{array}{c}\text { after } \\
2 \mathrm{~h}\end{array}$ & $\begin{array}{c}\text { after } \\
6 \mathrm{~h}\end{array}$ & $\begin{array}{c}\text { after } \\
10 \mathrm{~h}\end{array}$ & $\begin{array}{l}\text { after } \\
14 \mathrm{~h}\end{array}$ & $\begin{array}{c}\text { after } \\
18 \mathrm{~h}\end{array}$ & $\begin{array}{l}\text { after } \\
24 \mathrm{~h}\end{array}$ & $\begin{array}{l}\text { after } \\
32 \mathrm{~h}\end{array}$ & $\begin{array}{l}\text { after } \\
40 \mathrm{~h}\end{array}$ & $\begin{array}{l}\text { after } \\
48 \mathrm{~h}\end{array}$ \\
\hline 1. & Pure Zn & 80 & 100 & - & $\begin{array}{l}\text { Initiation } \\
\text { of red rust }\end{array}$ & & & & & \\
\hline 2. & $\mathrm{Zn}-0.20 \mathrm{Al}$ & 70 & 80 & 90 & 100 & - & $\begin{array}{l}\text { Initiation of } \\
\text { red rust }\end{array}$ & & & \\
\hline 3. & $\begin{array}{c}\mathrm{Zn}-0.20 \mathrm{Al}-0 \\
10 \mathrm{~Pb}\end{array}$ & 60 & 70 & 80 & 90 & 100 & - & $\begin{array}{c}\text { Initiation } \\
\text { of red } \\
\text { rust }\end{array}$ & & \\
\hline 4. & $\begin{array}{c}\mathrm{Zn}-0.25 \mathrm{Mg}-0 \\
.25 \mathrm{Al}-0.08 \mathrm{Si}- \\
0.08 \mathrm{Sb}\end{array}$ & 5 & 20 & 50 & 70 & 90 & 95 & 100 & - & $\begin{array}{c}\text { Initiatio } \\
\text { n of red } \\
\text { rust }\end{array}$ \\
\hline 5. & $\begin{array}{c}\mathrm{Zn}-0.50 \mathrm{Mg}-0 \\
.25 \mathrm{Al}-0.08 \mathrm{Si}- \\
0.08 \mathrm{Sb}\end{array}$ & 0 & 10 & 30 & 60 & 85 & 90 & 100 & & $\begin{array}{l}d \text { rust } \\
\text { ation }\end{array}$ \\
\hline 6. & $\begin{array}{c}\mathrm{Zn}-0.75 \mathrm{Mg}-0 \\
.25 \mathrm{Al}-0.08 \mathrm{Si}- \\
0.08 \mathrm{Sb}\end{array}$ & 0 & 10 & 30 & 50 & 80 & 90 & 100 & $\begin{array}{l}\text { No } \\
\text { for }\end{array}$ & $\begin{array}{l}d \text { rust } \\
\text { ation }\end{array}$ \\
\hline
\end{tabular}

In case of pure $\mathrm{Zn}, \mathrm{Zn}-0.20 \mathrm{Al}$ and $\mathrm{Zn}-0.20-0.10 \mathrm{~Pb}$ coated sheets, $100 \%$ white rust formation takes place within $6 \mathrm{hrs}$, $14 \mathrm{hrs}$ and $18 \mathrm{hrs}$. respectively, while in case of $\mathrm{Zn}-\mathrm{Mg}$-Al-Sb coated $100 \%$ white rust coverage on the sheet surface happens only after $32 \mathrm{hrs}$. of exposure. This happens because $\mathrm{Zn}-\mathrm{Mg}$ coatings inhibit the cathodic reaction and thus improve the corrosion resistance. The usual zinc carbonate hydroxide and zinc oxide observed in $\mathrm{Zn}-0.20 \mathrm{Al}$ and pure $\mathrm{Zn}$ coatings are suppressed in the presence of magnesium in the coating, and the whole surface is covered with zinc chloride hydroxide, which is protective for the coating layer.

\subsection{For mability property of $\mathrm{Zn}$-Mg Coated Sheets}

The formability characteristics of the newly developed coated sheets were quantified in terms of erichsen cup value of the composite. In the simulated GI sheets, erichsen cup value $(\mathrm{Ev})$ of the co mposite varied in the range of $8.8 \mathrm{~mm}$ to $10.4 \mathrm{~mm}$ depending on the bath composition and processing conditions of the sheet. Effect of bath temperature and dipping time on the Ev value of the coated sheets has been shown in Fig.5.

It can be seen that with increase in dipping time (for a particular bath composition and bath temperature), Ev value decreases slightly. This may be attributed to the fact that with increase in residence time, the thickness of alloy layer (Fe-Zn intermetallics), increases slightly. However, with increase in bath temperature (for a particular bath composition and dipping time), Ev value improves. Generally, formability of the galvanized sheets decreases 
with increase in bath temp., as increase in the bath temperature is generally associated with enhancement in the kinetics of the formation of Fe-Zn IMCs. However, in this case, due to presence of adequate $\mathrm{Si}(0.08 \%)$ and $\mathrm{A} 1(\sim 0.25 \%)$ in the zinc bath, tendency for the formation of Fe-Zn IMC gets significantly reduced (as shown in Fig.6). and this leads to improvement in formability characteristics of the coated sheets.

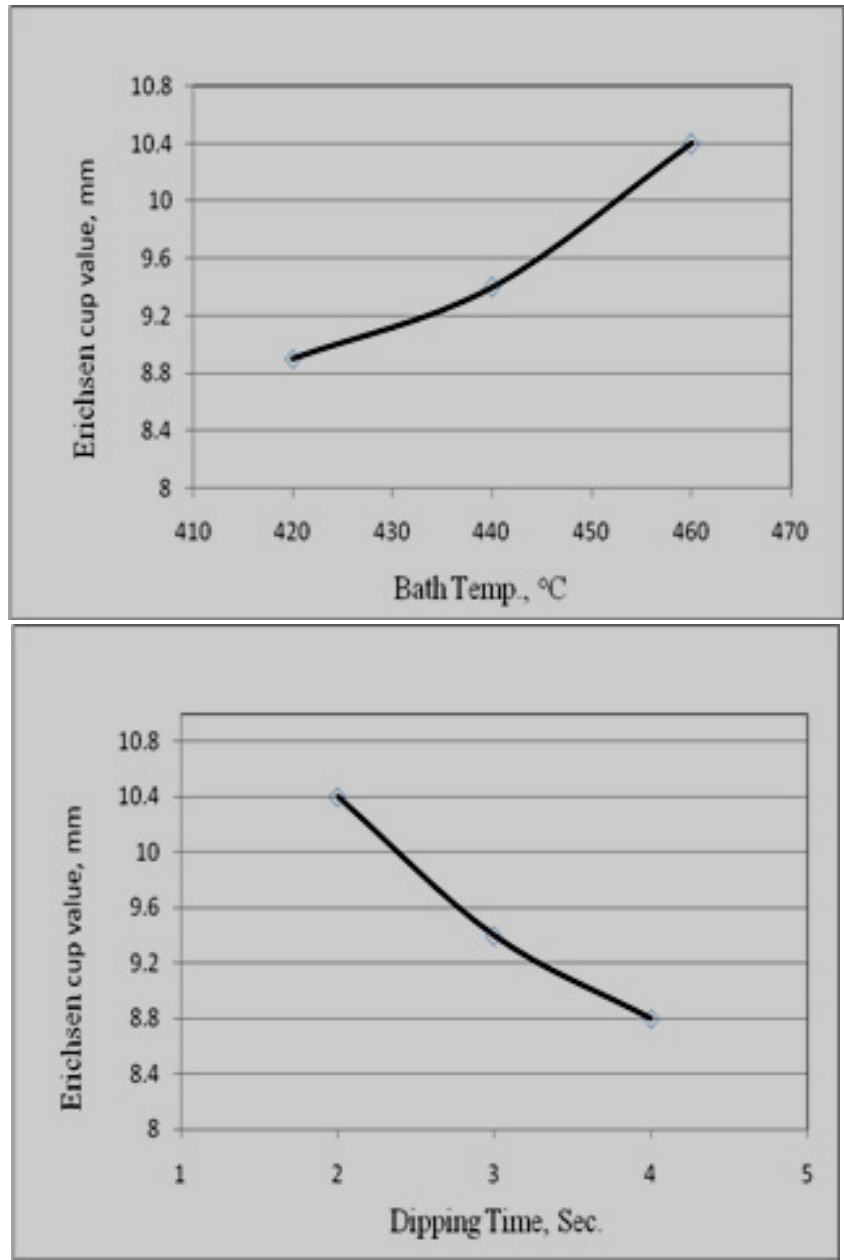

Figure 5. Influence of bath temp. and dippingtime on formability property of $\mathrm{Zn}-\mathrm{Mg}$ coated sheets

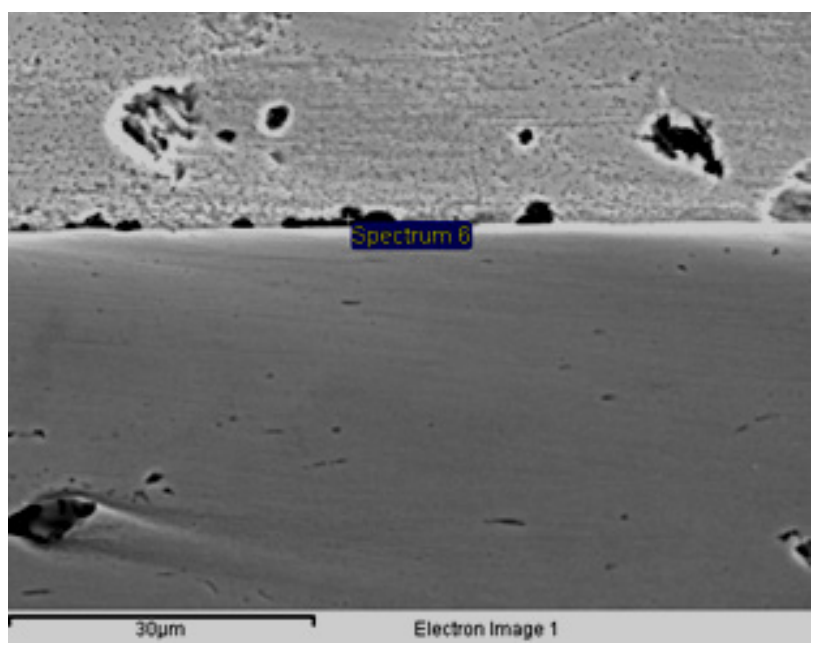

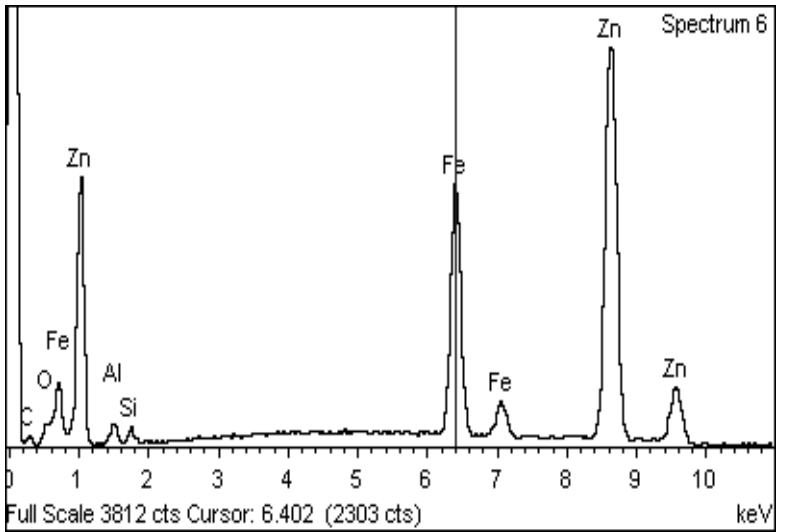

Figure 6. Microstructure and EDAX analysis of $\mathrm{Zn}-\mathrm{Mg}$ coated sheet showing presence of $\mathrm{Si}$ and $\mathrm{Al}$ at the coating-Steel interface
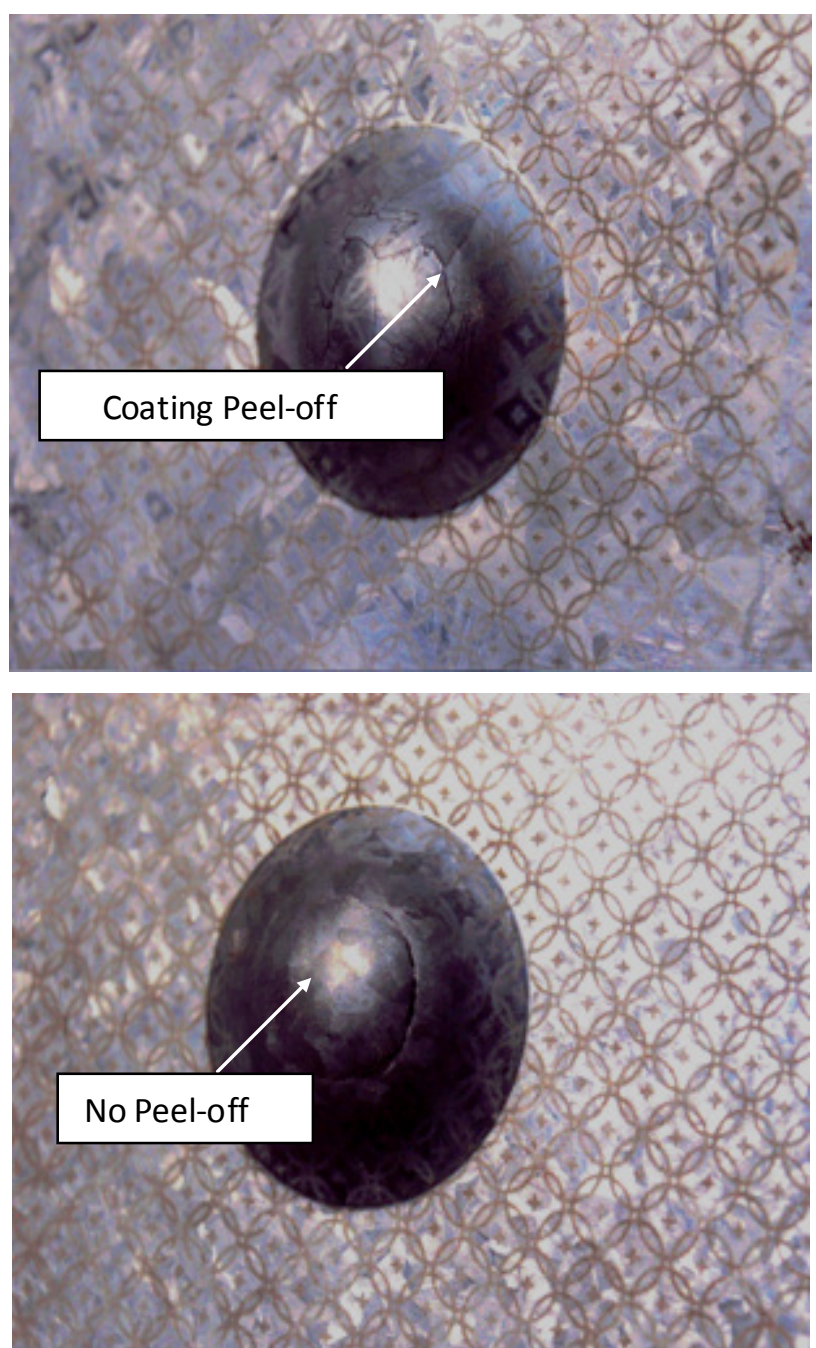

Figure 7. Strain analysis in formed component of (a) Conventional GI sheet (b) Zn-Mg coated sheet

In order to assess the forming capability of $\mathrm{Zn}-\mathrm{Mg}$ coated sheets in actual stamping operation, grid marking of coated sheets were done and subsequently these sheets tested in Erichsen cup tester. The coated sheets were deformed till fracturing of the composite. Strain level near the fracture zone was measured through transparent scale. It has been found that newly developed $\mathrm{Zn}-\mathrm{Mg}$ coated sheets can be 
safely deformed upto $30 \%$ strain. No cracks were visible even at fracturing of the composite. However, in conventional zinc coated sheets, even at $25 \%$ strain level cracks can be seen in the coating before the fracturing of the composite (as shown in Fig.7.).

\subsection{Ass ess ment of Coating Adherence}

Coating adherence of the $\mathrm{Zn}-\mathrm{Mg}$ coated sheets was assessed through Lock Forming Tester. Most of the sheets man ifested excellent coating adherence (as shown in Fig. 8), no cracks were observed near the bend portion. However, in some cases, minor cracks were observed.
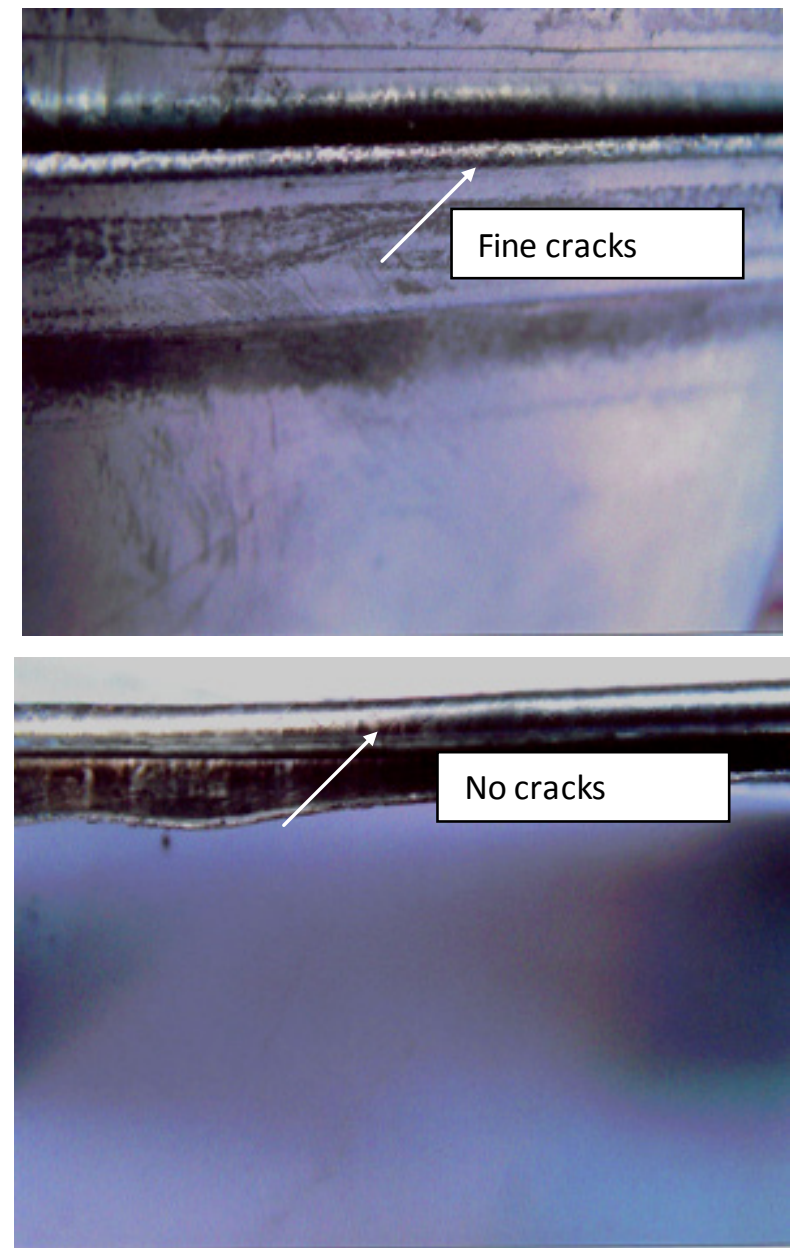

Figure 8. Lock Forming Tested Specimen with (a) poor and (b) excellent coat ing adherence of $\mathrm{Zn}-\mathrm{Mg}$ coated sheet

On examining these samples, it has been found that most of these samples were processed at lower bath temperature $\left(420{ }^{\circ} \mathrm{C}\right)$ for higher dipping time $(4.0 \mathrm{sec}$.). Due to lower solubility of $\mathrm{Si}$ at this temperature and higher residence time of the strip at this temperature, some formation of Fe- $\mathrm{Zn}$ IMC does take place and this leads to poor coating adherence. In some of the samples, poor coating adherence was observed due to entrapment of $\mathrm{Sb}$ containing exogenous compound (having composition $\mathrm{Sb}: 75.38 \%, \mathrm{Mg}: 18.85 \%$, $\mathrm{Zn}: 5.76 \%$ ), as shown in Fig.9. This must have happened due to improper mixing of $\mathrm{Sb}$ (due to its higher melting point) in the zinc bath.
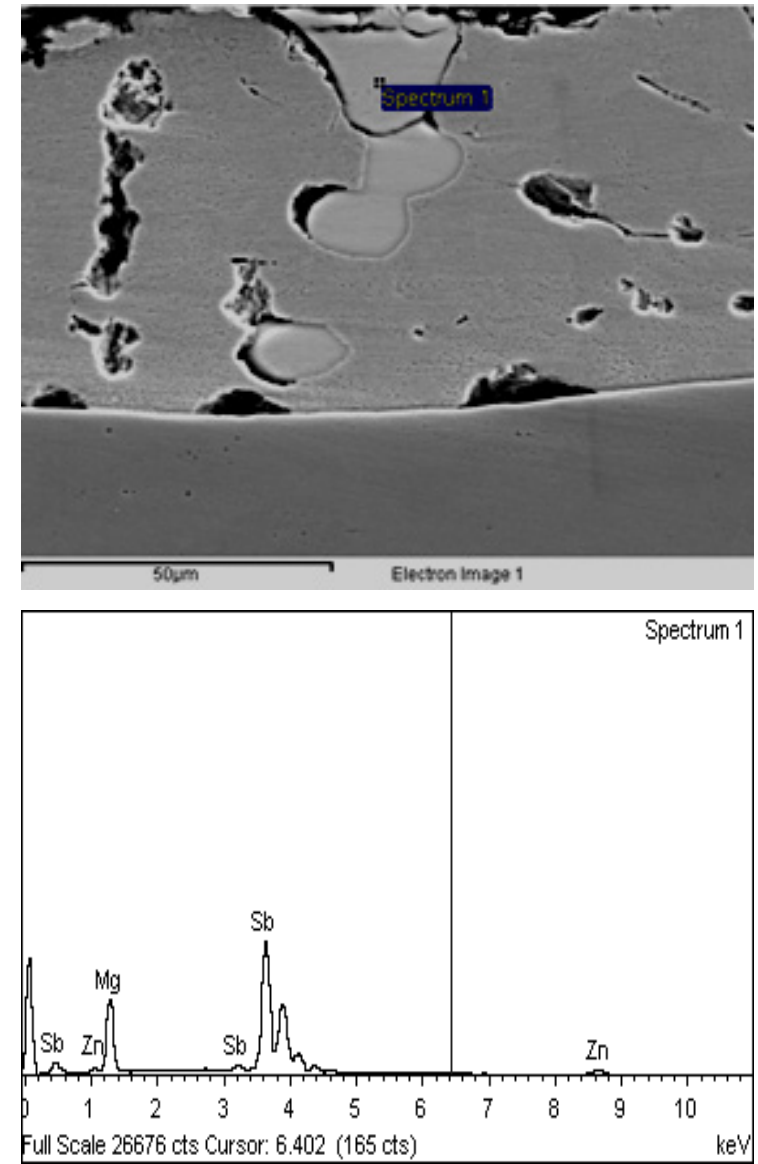

Figure 9. Microstructure and EDAX analysis of $\mathrm{Zn}-\mathrm{Mg}$ coated sheet showing entrapment of exogeneous compound in the coating

\section{Conclusions}

Based on the work carried out, following conclusions can be drawn :

- Addition of $\mathrm{Mg}(0.50-0.75 \%)$ and $\mathrm{Sb}(\sim 0.08 \%)$ in the zinc bath results in substantial improvement in corrosion resistant properties of the zinc coated sheet due to formation of $\mathrm{Zn} / \mathrm{Al} / \mathrm{Mg}$ eutectic mixture at grain boundaries and distribution of $\mathrm{Sb}$ within the coating.

- $\mathrm{Si}(\sim 0.08 \%)$ addition along with $\mathrm{Al}(\sim 0.25 \%)$ in the bath leads to complete suppression of the formation brittle $\mathrm{Fe}-\mathrm{Zn}$ intermetallics at the coating-steel interface, thereby resulting in significant improvement in the coating adherence and formability properties of $\mathrm{Zn}-\mathrm{Mg}$ coatings.

- $\mathrm{Zn}-0.50 \% \mathrm{Mg}-0.25 \% \mathrm{Al}-0.08 \% \mathrm{Si}$ coated steel sheets with imp roved corrosion resistance $\left(1 / 3^{\text {rd }}\right.$ w.r.t conventional $\mathrm{Zn}$ coated sheets), formability properties (at par with substrate material) and coating adherence (as per LFQ standard) with bright and smooth appearance have been successfully developed in the laboratory.

\section{ACKNOWLEDGEMENTS}

The authors are grateful to the management of Research \& Development Centre for Iron \& Steel, Ranchi for their 
constant support and encouragement during the course of work acco mplished under this project.

\section{REFERENCES}

[1] J. Kawafuku, J. katosh, M. Toyama, H. Nishimoto, K. Ikeda and H. satoh, "Structure and corrosion resistance of Zinc alloy coated steel sheets obtained by continuous vapor deposition apparatus", Tetsu-to-hagane, 77, 1991, 995-1002.

[2] H. Shindo, K. Nishimura and K. Saito, "Anti-corrosion in atmospheric Exposure of Zn-Mg-Al Hot-dip Galvanized steel sheet", Proc. Of 4th Int. Conf. on Zinc and Zinc alloy coated steel sheet, Galvatech'98, Tokyo, Japan, 1998, 433-436.

[3] Takao Tsujimura, Atsushi Komatsu, Atsushi Andoh, "Influence of $\mathrm{Mg}$ content in coating layer and coating structure on corrosion resistance of Hot-dip Zn-Al-Mg Alloy Coated Sheet, 5th int. Conf. on Zinc and Zinc alloy coated steel sheet, Galvatech'01, Brussels, Belgium, 2001, 145-152.

[4] S.J. Kim, Y. Mizutani, R. Ichino, M. Okido, "Surface morphology and electrochemical property of $\mathrm{Mg}$-Al alloys anodized in alkaline solutions and sealed, 203rd meeting-Paris, France, April, 2003, 244.

[5] Shiwei Li, Bo Gao, Ganfeng Tu Yi Hao, Liang Hu and
Shaohua Yin,"Study on the corrosion Mechanism of Zn-5Al-0.5Mg-0.08Si Coating", Journal of Metallurgy, Volume 2011, 2011, Article ID 917469, 5 pages

[6] R. Hausbrand, M. Rohwerder, M. Stratmann, C. Schowerdt, B. Schumacher, G. Grundmeier, "Model study on the corrosion of $\mathrm{Mg}$ containing zinc coatings on the steel sheet", 5th int. Conf. on Zinc and Zinc alloy coated steel sheet, Galvatech'01, Brussels, Belgium, 2001, 161-167.

[7] T. Prosek, A. Nazarov, U. Bexell, D. Thierry, J. Serak, Corrosion properties of model Zinc-Magnesium alloys, 7th Int. Conf. Zinc and Zinc alloy coated steel sheet, Galvatech'07, Osaka, Japan, 2007, 592-597.

[8] S. Tanaka, K. Hoda, A. Takahashi, Y. Morimoto, M. Kurosaki, H. Shindou, K. Nishimura, M. Suguyama, "The performance of Zn-Al-Mg-Si Hot-Dip Galvanized Steel Sheet", 5th int. Conf. on Zinc and Zinc alloy coated steel sheet, Galvatech'01, Brussels, Belgium, 2001, 153-160.

[9] S. Schuerz, M. Fleischanderi, G.H. Luckeneder, K. Preis, T. Haunschmied, G. Mori, A.C. Kneissi, "Corrosion bevahior of $\mathrm{Zn}-\mathrm{Al}-\mathrm{Mg}$ Coated steel sheet in sodium chloride-containing environment", Corrosion Science, Vol. 51, Issue 10, October 2009, 2355-2363.

[10] Monojit Dutta, Arup Kumar Halder, Shiv Brat Singh,"Morphology and properties of hot dip $\mathrm{Zn}-\mathrm{Mg}$ and Zn-Mg-Al alloy coatings on steel sheet", Surface and coating Technology, Vol.205, Issue 7, December 2010, 2578-2584. 